\title{
Obligation to Open Access: Academic Publishing of the Future?
}

Fabienne Sarah Graf / Dario Henri Haux *

Open Access is the principle of free access to scientific literature. Both the Swiss National Science Foundation and Swissuniversities are increasingly promoting Open Access. With this, the question arises, as to whether university employees may be obliged to publish Open Access. The authors describe in a first step, how this issue has been addressed in other countries, and then consider a possible implementation in Switzerland.

Introduction 125

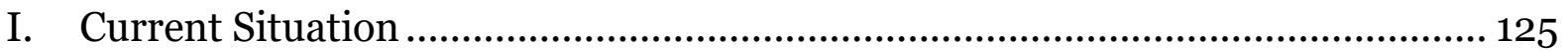

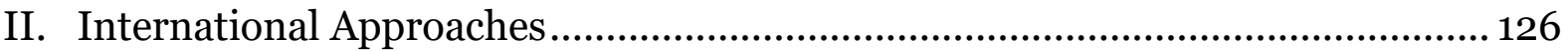

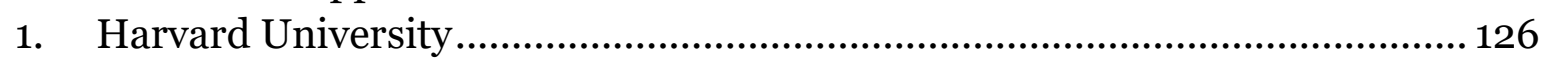

2. University of Suffolk: UK Scholarly Communication License (UK-SCL) ...... 128

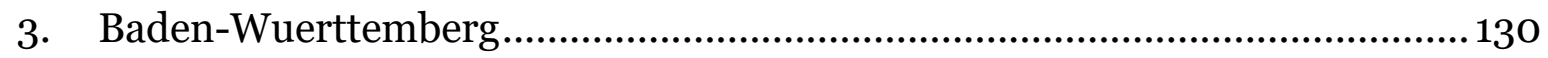

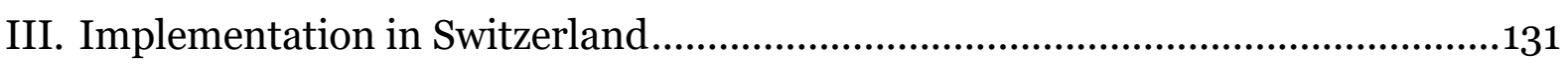

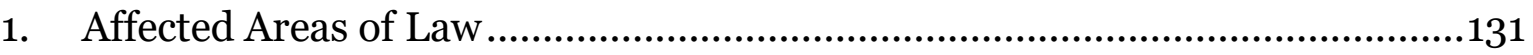

2. The Example of the University of St.Gallen and the National Science

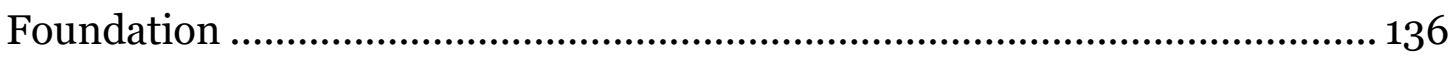

3. Challenges for the Establishment of OA Obligations ............................... 137

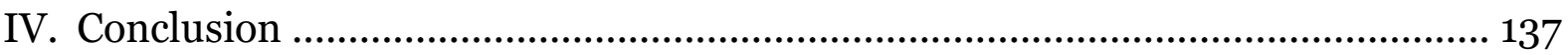

Citation: $\quad$ Fabienne Sarah Graf/Dario Henri Haux, Obligation to Open Access: Academic Publishing of the Future?, in: sui-generis 2018, S. 124

URL: $\quad$ sui-generis.ch/63

DOI: $\quad$ https://doi.org/10.21257/sg.63

* Fabienne Sarah Graf (fabienne.graf[at]unilu.ch), master student of law at the University of Lucerne, student assistant of Prof. Dr. Malte Gruber, Chair of Legal Philosophy and Commercial Law with a focus on Intellectual Property Law and the Law of New Technologies, University of Lucerne. Dario Henri Haux (dario.haux[at]unilu.ch), first German state examination, research assistant and doctoral candidate at the above Chair. The authors thank Dr. iur. Matthias Seemann and Prof. Dr. iur. Malte Gruber for their many valuable comments. The present work is an updated and translated version of Fabienne Graf/Dario Haux, Verpflichtung zu Open Access - universitäres Publizieren der Zukunft?, in: sui-generis 2017, S. 229. For the proofreading of this translation, the authors thank the Research Commission of the University of Lucerne, as well as Ass.-Prof. Dr. Catalina Goanta. 


\section{Introduction}

In the September issue of the Swiss journal for judges («Justice - Justiz Giustizia»), a practitioner expressed criticism regarding the proportional distribution («Parteienproporz») of judges according to party affiliation and related mandate taxes. ${ }^{1}$ When current developments in such a forum are being discussed, their relevance for the law is undisputed. At the same time, only a small group of people can access these comments. The password-protected area is only available to subscribers. Should they not be openly accessible? Are there reasons to take action, so that scholarly publications can be made accessible for everyone? In particular the adoption of the Swiss National Strategy on Open Access (OA) and the following action plan («Aktionsplan»), approved in February 2018 by the plenary assembly of Swissuniversities, puts this issue on the agenda in Switzerland. The strategy and action plan place great emphasis on flexibility for the universities, especially in the process of adapting the framework. ${ }^{2}$

Nevertheless, many aspects still remain unclear. While there are many factors, which play a role in the discussion, this paper will focus on making an inventory of the legal regimes which govern the question of $\mathrm{OA}$ in different jurisdictions. One of the said unresolved issues, related to the relationship between researchers, their home institutions, publishers and society, with a doctrinal focus on identifying and interpreting the rules applicable to OA, is the subject of this

Giuliano Racioppi, Die moderne "Paulette": Mandatssteuern von Richterinnen und Richtern, in Justice - Justiz - Giustizia, 2017/3.

2 Swissuniversities, Aktionsplan, p. 9. publication: Can and should university employees be obligated to provide Open Access to their publications?

\section{Current Situation}

3 In the various academic disciplines, different OA approaches, models and attitudes can be found. 3 While OA journals have gained a strong footing in the natural sciences in particular, 4 conventional journal publishing is still dominating the market in the legal sphere. 5 This prominent position of publishers in the field of print and digital journal subscriptions has led to increasing costs for libraries in recent years. 6 Only very few people are aware of the sums actually paid by the libraries. 7 Declining library

3 On the glaring differences between natural and social sciences, see Michael Link, Open Access im Wissenschaftsbereich, Diss., ErlangenNuremberg 2013, Frankfurt am Main, 2013, p. 115. Daniel Hürlimann/Alexander Grossmann, Open Access als Utopie?, in Informationspraxis, 2017, p. 2.

4 See the initiative of the Sponsoring Consortium for Open Access Publishing in Particle Physics or Quantum. For young researchers, new publishing possibilities are made possible by the Emergent Scientist or cognitio.

5 Hanjo Hamann, Freier Zugang zur juristischen Fachliteratur im Spiegel der Open-ScienceBewegung, in sui generis, 2016, p. 96 ff., p. 102; Thomas Pflüger/Dietmar Ertmann, E-Publishing und Open Access - Konsequenzen für das Urheberrecht im Hoch-schulbereich, in ZUM, 2004, p. 436 ff., p. 436. Eric W. Steinhauer, Das Recht auf Sichtbarkeit, Münster, 2010, p. 17. For a critical view on the possible consequences to the publication system, see Christian Russ, Freier Zugriff auf wissenschaftliche Beiträge?, in ZRP, 2004, p. $247 \mathrm{ff}$.

6 Pflüger/Ertmann (fn. 5), p. 437.

7 A sample summary of the costs can be found here. For the call for disclosure of the publication fees, made in June 2016 by the Alliance of Scientific Organizations in Germany, see Thomas Hartmann, a Legal Agenda for Digital Content, in RBD, 2016, p. 21 ff., p. 27. The question of whether a sufficient public interest exists for insight into the publishing contracts of Swiss academic libraries was negated by the Federal Court 
budgets and the sheer increase in information volume, mean that a significant portion of scholarly literature is no longer accessible. Hence, the interest in $\mathrm{OA}$ is growing. Theoretically, and from the perspective of a publishing scholar, two paths that can be taken. Firstly, the publication in a journal, which provides content freely accessible online - the «gold road».8 Secondly, the «green road», which takes a publication that has previously been published elsewhere and makes it available in an online repository. 9

4 Another dimension is the institutionalization of the idea of OA. Recent developments, such as the aforementioned action plan under the national $\mathrm{OA}$

(judgment 1C_4O/2017, July 5, 2017). With specific reference to the information-friendly information and privacy law legislation of the Canton of Basel-Stadt, the judges considered it reasonable to put private and public interests of a certain weight over the request for access (E. 6.2.2).

8 Eric Priest, Copyright and the Harvard Open Access Mandate, in NJTIP, 2012, p. 377 ff., p. $391 \mathrm{ff}$.

9 For possible organizational models of repositories, see Margo Bargheer/Saskia Bellem/Birgit Schmidt, Open Access und Institutional Repositories - Rechtliche Rahmenbedingungen, p. $16 \mathrm{ff}$., in Gerald Spindler (ed.), Rechtliche Rahmenbedingungen von Open AccessPublikationen, Goettingen, 2006, p. 1 ff. For the whole topic, see Reto M. Hilty/Matthias Seemann, Open Access - Zugang zu wissenschaftlichen Publikationen im schweizerischen Recht, commissioned by the University of Zurich, Zurich, 2009, p. $16 \mathrm{ff}$. OA supporters prefer the publication on their own websites («selfarchiving»); see Alma Swan, The Culture of Open Access. Researchers' Views and Responses, in Neil Jacobs (ed.), Open Access: Key Strategic, Technical and Economic Aspects, Oxford, 2006, p. 65 ff., p. 71. See also Bargheer/Bellem/Schmidt (fn. 9), p. 8. For repositories, see the IUWIS project, Institute for the Library and Information Science at the Humboldt University of Berlin, «Handreichung 'Zur urheberrechtlichen Gestaltung von Repositorien' für Universitäten, Forschungszentren und andere Bildungseinrichtungen». strategy, ${ }^{10}$ have made the topic appear political. ${ }^{11}$ According to Vision 2024, the aim was to have 100 percent of the publications from Swiss universities published OA by the year 2024. ${ }^{12}$ Meanwhile, the University Council of the Swiss University Conference has approved the action plan. ${ }^{13}$ These institutionalization steps stand between the poles of national and international copyright law on the one hand, and the idea of OA as global scholarly communication on the other. ${ }^{14}$ In practice, different forms of institutionalizing OA have been developed, with specific features determined by their geographic perimeters. Some of them, by practical relevance, will be presented in the following.

\section{International Approaches}

\section{Harvard University}

5 In 2008, the Faculty of Arts and Sciences at Harvard University unanimously voted in favor of transferring the non-exclusive rights of its researchers' writings, on all forms of non-commercial use, to the

10 Swissuniversities, Open Access, chap. 1.

11 See Nicola von Lutterotti, Freier Zugang zur Wissenschaft, NZZ Online, June 3, 2016.

12 National Open Access Strategy, 4. Vision, p. 3.

13 Swissuniversities, Open Access. The plan of action proposes an approach that combines the three basic options (green road, gold road, offsetting road). See Aktionsplan, p. $8 \mathrm{f}$. Not a topic of this paper, but nevertheless an essential decision factor for or against the individual scenarios, are the costs. Scholarly papers delving deeper into this topic would be desirable.

14 For the limitations of the democracy-determined framework, see Thomas Hartmann, Open Access rechtlich absichern - warum es ein Opt-in braucht, in Konstanze Söllner/Bernhard Mittermaier (eds.), Praxishandbuch Open Access, Berlin, 2017, p. 45 ff., p. 46. 
university. ${ }^{15}$ Other institutions followed. ${ }^{16}$ From the perspective of copyright, the mentioned model is nothing more than a non-exclusive license. 17 The university will gain the rights to all works by their own employees. ${ }^{18}$ Once the university has received the final works, they will be saved in the DASH repository, 19 accessible to anyone without registration. A not-for-profit and non-derivative use by third parties is possible, but must conform to the DASH conditions of use. ${ }^{20}$ As a rule, the universities are trying to get written grant licenses. ${ }^{21}$ Storage in the DASH repository, if stored as a first

15 See Robert Mitchell, Harvard to Collect, Disseminate Scholarly Articles for Faculty, Harvard Gazette, February 14, 2008; Priest (fn. 8), p. 381, p. 396. The implementation is based on an approach of the US National Institute of Health (NIH) of 2005; see Orit Fischman Afori, The Battle Over Public E-Libraries - Taking Stock and Moving Ahead, in IIC, 2013, p. 392 ff., p. 398; Priest (fn. 8), p. 398.

16 An enumeration of the organizations can be found in Priest (fn. 8), p. 396. For the influence of this Ivy League university in the process, see Peter Suber, The Open Access Mandate at Harvard, in SPARC Open Access Newsletter, no. 119, 2008; Philip Young, The Serials Crisis and Open Access: A White Paper for the Virginia Tech Commission on Research, Virginia Polytechnic Institute and State University, 2009.

17 Priest (fn. 8), p. 381 . See also FAQ to the Harvard-Model the Website of the UK Publishers Association.

18 See Ellen Finnie Duranceau/Sue Kriegsman, Implementing Open Access Policies Using Institutional Repositories, in Pamela Bluh/Cindy Hepfer (eds.), The Institutional Repository: Benefits and Challenges, Chicago, 2013, p. 75 ff., p. 79.

19 Digital Access to Scholarship at Harvard. A collaboration between the Office for Scholarly Communication (OSC) and the Office for Information Systems (OIS), two programs from the Harvard University Library; see Peter Kosewski, Harvard's DASH for Open Access, Harvard Gazette, August 31, 2009.

20 The wording is similar to that of the Budapest Initiative.

${ }^{21}$ Michael W. Carroll, Complying with the NIH Public Access Policy: Copyright Considerations and Options, SPARC, 2008; Priest (fn. 8), p. 432. publication, thus corresponds to a gold road publication in another medium. ${ }^{22}$

6 Still, exemptions from this obligation to OA, known as «waivers», remain possible. Provisions are also made in respect to possible embargo periods on the part of the repository. ${ }^{23}$ But how can a person employed at the university as a researcher benefit from the aforementioned exemption («opt out»)? To do so, they must apply to the dean of the faculty - sometimes with the requirement of giving reasons. Most of the time, the exemption is approved. ${ }^{24}$ However, such requests are only made in about five percent of cases. ${ }^{25}$ A second exception to the OA obligation is referred to as the «dark deposition». Here, contractual provisions between the researcher (author) and the publisher preclude the work from simultaneously being made accessible in the repository. After the expiration of an approximately six-month embargo, the «lift date» is reached and the publication is made public for everyone. ${ }^{26}$

$22 \overline{\text { Axel Metzger, Die urheberrechtliche Gestaltung }}$ von Open Access Repositorien, Report, in IUWIS Handreichung (fn. 9), p. 55.

23 See the wording of the Open Access Policy of the Harvard Faculty of Arts and Sciences; Priest (fn. 8), p. 381 ff., 397 f. It is also described as «opting out». In practice, less than 5 percent of the cases apply for waivers; see Chris Banks, Focusing Upstream: Supporting Scholarly Communication by Academics, in UKSG Insights 29, 2016, p. 37 ff., p. 42; see also Duranceau/ Kriegsman (fn. 18), p. 79.

24 See the duty of justification in the Harvard Law School Open Access Policy: «The Dean or the Dean's designate will waive application of the policy to a particular article upon written request by a Faculty member explaining the need.»

25 Stuart Shieber/Peter Suber, Good Practices for University Open-Access Policies (2013), Cambridge, MA: Harvard, Open Access Project; Young (fn. 16), p. $7 \mathrm{f}$.

26 Harvard Library, Office for Scholarly Communication, Author Frequently Asked Questions. 
7 Despite the continued success of this model, discussions about the infringement on academic freedoms will continue. The researcher is no longer able to decide where, when and what to publish. ${ }^{27}$ Another, sometimes technical, challenge is the classification of the different versions. In the databases, a distinction is made between the author's manuscript, the published version and other versions. ${ }^{28}$ The distinction is crucial, with some publishers prohibiting the distribution of the «version of record», the final version of the publisher. ${ }^{29}$ What remains unclear are the criteria for rejecting or accepting the waiver. While some faculties require extensive justifications, others grant approval without further inquiry. $3^{\circ}$ In relation to the specific situation in the United States, it is also

$27 \overline{\text { For the current state of discussion in Germany, }}$ see Matthias Mönch/Jens M. Nödler, Hochschulen und Urheberrecht - Schutz wissenschaftlicher Werke, in Gerald Spindler (eds.), Rechtliche Rahmenbedingungen von Open AccessPublikationen, Göttingen, 2006, p. 21 ff., p. 40; Pflüger/Ertmann (fn. 5), p. 441; Arthur-Axel Wandtke/Winfried Bullinger, Praxiskommentar zum Urheberrecht, § 43 UrhG, 4th ed., Munich, 2014, note 40-43.

28 Of particular relevance is the "version of record», as the publisher's final version, as opposed to the author's manuscripts; see Daniel Rothchild/Stuart Shieber, Automatically Determining Versions of Scholarly Articles, in SRC, 2017, p. 2; see also Melanie Bosshart, Das CreativeCommons-Lizenzsystem, Diss., Zurich 2013, p. 227.

29 An automated test procedure using machine learning algorithms (logistic regression) is proposed here, which has already been proven in direct comparison with manual testing by experts. For the whole topic, see Rothchild/Shieber (fn. 28), p. 1 ff.; see also Duranceau/Kriegsman (fn. 18), p. 81.

30 For a critical approach, see Karin Wulf/Simon Newman, Missing the Target: The UK Scholarly Communications License, in The Scholarly Kitchen, 2017. The authors see the waiver option as a possible way of bypassing the system - and in this «more of a statement of institutional preference than a directive». questionable whether the statutory «work made for hire» scheme ${ }^{31}$ could result in the university, as the employer, being regarded as the author, rather than the researcher herself or himself. 32

8 Nevertheless, the Harvard model appears as a useful complement to the US legal system concerning copyrights. One reason is, that the system alone - even with its limitations and exceptions for the benefit of education, science and archiving - does not meet the full potential of the new technologies for educational institutions. 33

\section{University of Suffolk: UK Scholarly Communication License (UK-SCL)}

9 In the United Kingdom, a variety of OA approaches and institutional regulations has evolved.34 Here, some universities already have a budget for gold road publications. In this context, OA approaches

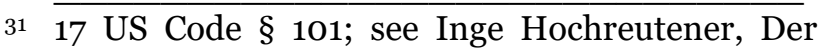
Verlagsvertrag, Art. 380-393 OR, in Jörg Schmid, Kommentar zum schweizerischen Zivilrecht, 4th ed., Zurich, 2011, p. 20.

32 For a critical example, see for instance Priest (fn. 8), p. $400 \mathrm{ff}$. This scenario is possible, in particular because the US copyright system (unlike continental European law) does not acknowledge any moral rights in the true sense of the word and therefore draws on legal usage; see Hochreutener (fn. 31), p. 20.

33 See Philipp Usadel, Copyright Law and the Access to Education and Knowledge in the Digital Age: Matching Limitations and Exceptions in Portugal, Brazil and Mozambique, Aachen, 2016, p. 172 f. On the influence of the prominence of this Ivy League university, see Suber (fn. 16). For the US copyright system, see Lawrence Lessig, The Creative Commons, Montana Law Review, 2007, 65, p. $4 \mathrm{ff}$.

34 Elizabeth Gadd, UK University Policy Approaches towards the Copyright Ownership of Scholarly Works and the Future of Open Access, in Aslib Journal of Information Management, 2017, p. 95 ff., p. 97. 
are being discussed 35 and increasingly supported. ${ }^{6}$ At the University of Sussex, for example, an approach 37 based on the Harvard model is being pursued. 38 In addition to making writings available in a database, a focus is placed on the reuse of the stored works. 39 This is done by means of standardized Creative Commons (CC) licenses, which enable third parties to use the particular work.40 The author himself or herself can decide about the rights enjoyed by other users. ${ }^{41}$ Proponents of this approach stress that CC licenses better meet the needs of the copyright owner, compared to the traditional reward-based system. ${ }^{2}$ This model differs from the Harvard model due to its use of CC licenses. However, according to the DASH conditions, a subsequent use is possible there too.

35 Banks (fn. 23), p. 39 f. See also the Finch Report 2012 (Report of the Working Group on Expanding Access to Published Research Findings) and the Response of the BIS (UK Department for Business Innovation and Skills) from July 16, 2012.

36 UK Scholarly Communications Licence, University of Suffolk, p. 8.

37 See UK Scholarly Communications Licence, University of Sussex (fn. 36), p. 1. There as well (as under the Harvard model), the obligation to publish OA is determined within the university.

38 The university itself provides a model guideline for adaptation by other institutions. The Imperial College London has had a pioneering role in the development of such a guideline; see Gadd (fn. 34), p. $97 \mathrm{f}$.

39 Hartmann, Opt-in (fn. 14), p. 48.

40 UK Scholarly Communications Licence, University of Suffolk (fn. 36), p. 5; see Hartmann, Opt-in (fn. 14), p. 48.

41 Michael Fehling, Von der kommerziellen Verlagsproduktion zum Open Access - Zur Rolle des Rechts beim Wandel wissenschaftlicher Publikationskanäle, in Wolfgang Hoffmann-Riem (ed.), Innovationen im Recht, Baden-Baden, 2016, p. 337 ff., p. 342; Lessig (fn. 33), p. 11.

42 Bosshart (fn. 28), p. 63. The reward would be in the promotion of original writings. Regarding the compatibility of the licensing with national law, see Miriam Sahlfeld, Creative Commons, in Medialex, 2007, p. 72 ff., p. 74 ff.
10 At the University of Suffolk, under the «UK Scholarly Communications License», the «CC-BY-NC» basic form of the CC license is applied.43 This is comprised of the «attribution» («BY») and the «noncommercial use» («NC») components. Possible additions can include the «share alike» («SA») and «no derivatives» («ND») components.44 The necessary precondition for any type of use is the attribution of the work to the author. 45

11 Furthermore, the concept of the «moving wall» license is in use. The storage of the writing in the repository allows for metadata to be made visible. 46 The UK-SCL also provides for special exemptions. However, unlike the Harvard approach, more room is given for the institutions, whose conditions for refusing the waiver can be set forth individually. 47 This model, too, follows the assumption that the copyright of a work will be attributed to the author and not the university. 48

43 See for example the University of Suffolk: UK Scholarly Communications Licence, University of Suffolk (fn. 36), p. 5 .

44 Bosshart (fn. 28), p. 64 f.; see Lessig (fn. 33), p. 11.

45 Stuart M. Shieber, The Case for the Journal's Use of a CC-BY License, in JLM, 2012, p. 5 ff., p. 6.

46 Banks (fn. 23), p. 42. This also complies with the OA criteria of the major European funding vessels (e.g. the European Research Council ERC Grants); see Duranceau/Kriegsman (fn. 18), p. 87.

47 Gadd (fn. 34), p. 98.

48 See chap. III.1; Gadd (fn. 34), p. 98. See also the CDPA (Copyright Designs and Patents Act, 1988), wherein is stated, «Where a literary, dramatic, musical or artistic work, or a film, is made by an employee in the course of his employment, his employer is the first owner of any copyright in the work subject to any agreement to the contrary.» See Hochreutener (fn. 31), p. 20 f. For the actual survey of copyright claims in guidelines from UK universities, see Gadd (fn. 34), p. 105 ff., p. 111. In the omitted clarification of the controversial 


\section{Baden-Wuerttemberg}

12 In Germany, the idea of OA was promoted by the Alliance of Scientific Organizations («Allianz der Wissenschaftsorganisationen» 49 and, to the astonishment of many, by the legal committee of the Bundestag. 50 Section 38 para. 4 of the German Copyright Act (UrhG), which came into force on 1 January 2014, grants researchers, who finance their work predominantly with state funding, a nationwide self-activating republication ${ }^{51}$ right - after a contractually mandatory waiting period of one year. $5^{2}$ In the explanatory memorandum 53 of the German legislators, central justifications of the Open Access paradigm are being taken

copyright issue, in the cause for developing a framework for OA approaches, and in joint authorship, there are possibilities for resolving various problem areas related to OA.

49 See the Berlin Declaration on Open Access to Knowledge in the Sciences and Humanities, published on October 22, 2003, as a cornerstone; Marcus Hirschfelder, Anforderungen an eine rechtliche Verankerung des Open Access Prinzips, Diss., Saarbruecken 2007, p. $10 \mathrm{ff}$.

50 See Resolution («Entschliessung») June 26, 2013, p. 2 ff.; Fehling (fn. 41), p. 340. For the requirements of EU law, see Daniel Krausnick, Offene Wissenschaft? - Öffentlich-rechtliche Aspekte der Diskussion um Open Access und Open Data, in Max-Emanuel Geis/Markus Winkler/Christian Bickenbach (eds.), Von der Kultur der Verfassung, Festschrift für Friedhelm Hufen, Munich, 2015, p. 367 ff., p. $371 \mathrm{ff}$.

51 Regarding the controversial classification of this right as a barrier ( «Schrankenregelung») - not compatible with EU law - previous to the revision, see Hirschfelder (fn. 49), p. 138 f.; for a contrasting view, see Gerd Hansen, Für ein Zweitveröffentlichungsrecht für Wissenschaftler - zugleich Besprechung von Marcus Hirschfelder: Anforderungen an eine rechtliche Verankerung des Open Access Prinzips, in GRUR Int. 2009, p. 799 ff., p. 802 ff.

52 Ulrike Müßig, «Ein Knauf als Tür»: Open AccessVerpflichtung durch Forschungsförderung vs. Gemeinfreiheitsgrenzen digitaler Wissenschaftskommunikation, in JZ, 2015, p. 221 ff., p. 221, 229.

53 Deutscher Bundestag, Drucksache 17/13423, May 8, 2013, p. 9 f. into consideration for the first time.54 Furthermore, in 2017 the federal government voted to accept the «Draft Law on the Alignment of Copyright with the Current Requirements of the Knowledge Society» (UrhWissG). 55

13 The obligation to OA has been particularly notable since the third University Law Amendment Act of April 1, 2014 (3. HRÄG), and the adoption of $\S 44$ para. 6 of the State Higher Education Act (LHG) in Baden-Wuerttemberg. By statute, researchers are obliged to exercise their rights from the aforementioned $\S 38$ para. 4 of the Copyright Act. $5^{6}$ Thus, a disciplinary-juridical protection is in force. The right becomes a duty.57 Still, the question of the constitutionality of such an obligation arises. ${ }^{8}$ The Federal Constitutional Court (Bundesverfassungsgericht) places a researcher's

$54 \overline{\text { Hartmann, Opt-in (fn. 14), p. 48. What might }}$ appear progressive is also accompanied by legal concerns; see Müßig (fn. 52), p. $229 \mathrm{ff}$.

55 Deutscher Bundestag, Drucksache 18/12329, May 15, 2017; Katharina de la Durantaye, Neues Urheberrecht für Bildung und Wissenschaft - eine kritische Würdigung des Gesetzesentwurfs, in GRUR, 2017, p. $558 \mathrm{ff}$.

56 Manfred Löwisch, Förderung statt Zwang - Neue Open Access Strategie in Baden-Württemberg, in OdW, 2017, p. 59 f.; Georg Sandberger, Landeshochschulgesetz Baden-Württemberg, Kommentar, 2nd ed., Heidelberg, 2015, p. 21. The order to deposit the publication in a repository was previously made by an ordinance («Rechtsverordnung»), now by a statute of the university («Satzung der Hochschule»). The deadline is one year and is thus adjusted to $\S 38$ para. 4 UrhG (in the hearing draft, six months were planned); see Krausnick (fn. 50), p. 378.

57 Christian von Coelln/Volker M. Haug (eds.), BeckOK Hochschulrecht Baden-Württemberg, no. 20 on $\S 44$ LHG; Sandberger (fn. 56), p. 40.

58 Of major importance is the distinction between the right to secondary publication («Zweitveröffentlichungsrecht») and the duty thereof («Zweitveröffentlichungspflicht»); see Sandberger (fn. 56), p. 70; see Coelln/Haug (fn. 57), no. 21 on $\S 44$ LHG. 
decision about where to publish under the fundamental right of freedom of research (Art. 5 para. 3 Constitution Grundgesetz [GG]).59 In addition, the secondary publication requirement (Zweitveröffentlichungsrecht) contradicts $\S 3$ para. 2 LHG, in which the freedom of research is anchored.60 To these substantive aspects comes the question as to whether or not the federal states have legislative authority. The answer must be no if, in the process of determination, a barrier can be seen to copyright and thus substantive copyright law. ${ }^{61}$ Do individual rights for researchers consequently emerge from the LHG? The law directs the statute obligation to universities, not directly to individuals. ${ }^{62}$ Thus, the successful introduction of an OA obligation, as well as any actions against such a requirement, ultimately depend on the statutes of the respective universities and their implementation. ${ }^{63}$

59 BVerfG, Ruling («Beschluss») March 1, 1978, BVerfGE 47, 327, 367; Ruling January 11, 1994, BVerfGE 90, 1, 12; BGH Judgement («Urteil») September 27, 1990, BGHZ 112, 243 ff.; see Müßig (fn. 52), p. 231 f.; Krausnick (fn. 50), p. 378.

6o Freedom of research (Art. 5 para. 3, first sentence of the constitution [ «Grundgesetz»]) particularly includes the question, the principles of the methodology, and the evaluation of the results of the research and their dissemination. Sentence 1 applies accordingly to artistic development projects and to the practice of art ( $\$ 3$ para. 2 LHG); Sandberger (fn. 56), p. 40.

61 On the inhibition as a matter of national authority, see Art. 73 para. 1 no. 9 GG and Art. 71 GG; see also Krausnick (fn. 50), p. 378.

62 A lawsuit against the statute would have to be taken by the university; this, in turn, requires broad support across the faculty boundaries, but it may fail due to the different attitudes toward OA (see chap. II) and political orientations within the fields of study.

63 Proceedings against the first norm control («Normenkontrolle») were initiated by 17 professors from Konstanz at the Administrative Court of Baden-Wuerttemberg. By resolution of September 26, 2017, the latter asked the Federal

\section{Implementation in Switzerland}

14 The question of whether university employees may or should be obligated to OA cannot be answered solely from the perspective of university laws. Rather, recent legal developments, implementation approaches and future challenges must be taken into consideration. 64 This notably includes cantonal law, due to the universities' funding 65 as outlined in the federal law. The Federal Act on Funding and Coordination of the Swiss Higher Education Sector (Higher Education Act, HEdA), ${ }^{66}$ in particular, must be taken into account. 67

\section{Affected Areas of Law}

15 Open Access and any related obligation thus concerns various legal bases. In the following, aspects of constitutional,

Constitutional Court whether $\S 44$ (6) of the Landeshochschulgesetz (LHG) violated Art. 71, Art. 73 para. 1 no. 9 GG (see the Court's press release of November 6, 2017, and media reports on lto.de). In further consequence, the Court recognized an intrinsic connection of the matter to copyright, and, for this reason, a lack of legislative power. The decision will be suspended and brought to the Federal Constitutional Court. As other universities are planning to make their actions dependent on this decision, this process should not be underestimated; see the article in the Badische Zeitung: Sollen Wissenschaftstexte im Internet frei zugänglich werden? («Should scholarly texts be freely accessible on the internet?»).

64 This calculation was updated with the adoption of the national OA strategy by the plenary assembly of Swissuniversities on January 31, 2017, and thus the imminent actual implementation in Switzerland. See also, with a schedule, Swissuniversities, Open Access.

65 See Art. 63a BV, ZSAV-HV: generally cantonal; exceptions can be found at ETHZ and EPFL.

66 Of September 30, 2011; see Art. 1 para 1 HEdA.

67 See Fabian Amschwand, Qualitätssicherung im schweizerischen Hochschulwesen: Verfassungsrechtlicher Rahmen und Leitlinien für die Umsetzung an den Hochschulen, in Heinz Hausheer, ASR - Abhandlungen zum Schweizerischen Recht, no. 802, Bern, 2014, p. 15 ff., p. 23 f. 
copyright and competition law will be discussed in particular. A distinction will be made between the perspective of the university, and that of its research staff.

\section{a) Constitutional Law}

From a constitutional point of view, the first question is whether an obligation to OA could be supported by the scholarly freedom provided for in Art. 20 of the Federal Constitution of the Swiss Confederation (BV). ${ }^{68}$ Science, ${ }^{69}$ as a part of society's opinion-making process, requires a high degree of institutional embedding. $7^{\circ}$ For universities, as a prerequisite for the independence of researchers, this means organizational autonomy. ${ }^{71}$ This results in a directive to the state to promote scientific research and innovation (Art. 64 para. 1 BV).72

68 This question arises in the context of copyright law, public service law and university law. It is therefore considered as a central preliminary question. See also Steinhauer (fn. 5), p. 45.

69 The term «science» is not defined in the Swiss legal system; however, it is assumed in the material for $\mathrm{BV}$ and is not further discussed by the BG. See also Rainer J. Schweizer/Felix Hafner, Art. $20 \mathrm{BV}$, in Die Schweizerische Bundesverfassung, 4th ed., Zurich/St. Gallen, 2014, no. 8 on Art. 20; see Giovanni Biaggini, BV Kommentar, Zurich, 2007, p. $163 \mathrm{f}$.

70 Jörg Paul Müller/Markus Schefer, Grundrechte in der Schweiz, 4th ed., Bern, 2008, p. $544 \mathrm{ff}$. Freedom of science also needs this framework for development; see Biaggini (fn. 69), p. 163.

71 Müller/Schefer (fn. 70), p. 544. On the aspect of independence, even with state sponsorship of the university, see Regina Kiener/Walter Kälin, Grundrechte, 2nd ed., Bern, 2013, p. 268.

72 See Paul Richli, Von der Gelehrtenrepublik zur Managementuniversität?: Rechtsfragen der Organisation und Leitung von Universitäten in der Bundesrepublik Deutschland, Österreich, der Schweiz und den USA, Bern, 2009, p. 149. As a secondary protection objective, this obligation also extends to economic freedom (see Art. 27 and $94 \mathrm{BV}$ ) in the sense of the need for competition-neutral behavior; see Markus Müller, Akademische Freiheit, Sorgen um ein bedrohtes Gut, in Berner Gedanken zum Recht: Festgabe der Rechtswissenschaftlichen Fakultät der Universi-
Still, it needs to be clarified to what extent academic freedom is compatible with the claims of OA.

17 In general, academic freedom does appear to correspond with OA. An image of science whose main function is based on «cognition by method»73 benefits from the aim of free accessibility of scientific information. 74 A part of science is the distribution of such information in an open, rational discourse. 75 In addition to determining the respective publication for distribution, free publishing also involves having the option to choose the date and channel of publication. ${ }^{76}$ This aspect shows that an obligation to $\mathrm{OA}$ is in tension with academic freedom. Accordingly, such an obligation must take considerations of proportionality into account from the very start. 77

18 Not only the researchers as natural, but also as legal persons may have fundamental rights under Art. 20 BV. Still, it remains unclear if and how universities

tät Bern für den Schweizerischen Juristentag 2014, Bern, 2014, p. $381 \mathrm{ff} ., 388 \mathrm{f}$.

73 See Kiener/Kälin (fn. 71), p. 266. In a democratic constitutional state, no single understanding of science should be given preference. Rather, their plurality must define the term and thus the objects of protection; see Kiener/Kälin (fn. 71), p. 268; see also Müller/Schefer (fn. 70), p. 543.

74 See chap. II; see Nicole Schmidt, Open Access, Hochschulrechtliche Veröffentlichungs- und urheberrechtliche Anbietungspflichten des Hochschulprofessors, Diss., Dresden 2015, BadenBaden, 2016, p. 19, 47.

75 Schweizer/Hafner (fn. 69), no. 8 on Art. 20; see Kiener/Kälin (fn. 71), p. 267.

76 See Biaggini (fn. 69), p. 163; Schweizer/Hafner (fn. 69), no. 22 on Art. 20.

77 A restriction of Art. 20 BV must be seen in the light of Art. 36 BV; see Biaggini (fn. 69), p. 164. 
should be involved..$^{8}$ Academic freedom, as part of the third-party applicability of fundamental rights («Drittwirkung der Grundrechte»), not only applies in relation to the state, but must also be considered in the interpretation between private individuals. 79 In light of an $\mathrm{OA}$ obligation, the interpretation of the Federal Act on Copyright and Related Rights (Copyright Act, CopA) ${ }^{80}$ in particular appears primarily relevant. If and to what extent an interpretation of fundamental rights is relevant in practice, remains a matter of dispute. ${ }^{81}$ Yet the aim of the norm restricts interpretations from being too extensive. ${ }^{82}$ Furthermore, an interpretation is not automatically compliant with the Federal Constitution of the Swiss Confederation if it corresponds to academic freedom; rather, other constitutional provisions must be taken into consideration. ${ }^{83}$ One such example involves property rights. ${ }^{84}$ Intellectual property rights are considered a part of the property rights under Art. $26 \mathrm{BV} .85$ Interestingly enough, fundamental liberties and copyright law reflect diametrical-

$7 8 \longdiv { \text { Biaggini (fn. 69), p. 164. In the sense of autono- } }$ my, this is affirmed by the doctrine; see Kiener/Kälin (fn. 71), p. 266; see also Schweizer/Hafner (fn. 69), no. 22 on Art. 20.

79 BGE 120 V 312 ff. E. 3b; BGE 111 II 245 ff. E. 4b; see BGE 136 I 167 ff. E. 2.2.

8o Of October 9, 1992.

81 Hilty/Seemann (fn. 9), p. 22; denying the meaning.

82 See Thomas Gächter, Rechtsmissbrauch im öffentlichen Recht: Unter besonderer Berücksichtigung des Bundessozialversicherungssrechts. Ein Beitrag zu Treu und Glauben, Methodik und Gesetzeskorrektur im öffentlichen Recht, Zurich, 2005, p. 280 f. For a concurring view, see Hilty/Seemann (fn. 9), p. 22.

83 Schweizer/Hafner (fn. 69), no. 8 on Art. 20.

84 Hilty/Seemann (fn. 9), p. 22; see Schweizer/Hafner (fn. 69), no. 23 on Art. 20.

85 Ulrich Häfelin/Walter Haller/Helen Keller/ Daniela Thurnherr, Schweizerisches Bundesstaatsrecht, 9th ed., Zurich, 2016, no. 597. ly opposed interests. As a result of debates related to the digital age, this fact is moving into the public focus. ${ }^{86}$

\section{b) Copyright and Associated Issues}

19 Compared to other jurisdictions, ${ }^{87}$ the Swiss CopA offers flexible responses to the development of information technology. 88 This is facilitated by the design of the usage rights as a general clause, 89 with corresponding samples («Regelbeispiele»). 90 But do they also allow for an obligation to OA?91 From a copyright perspective, it seems clear that a university does not automatically hold the rights to works that their paid researchers produce. ${ }^{2}$ Therefore, a publication in

86 This tension is nothing new; see Sundara Rajan, Copyright and Creative Freedom: A Study of Post-socialist Law Reform, London, 2014, p. 26. See Hartmann, Opt-in (fn. 14), p. 45.

87 For examples from the German copyright law (UrhG), see Herbert Burkert/Peter Hettich/Florent Thouvenin/Rehana Harasgama, Remembering and Forgetting in the Digital Age A Position Paper, in Information Research, 2016, p. 60; see also Thomas Dreier, Urheberrecht auf dem Weg zur Informationsgesellschaft - Anpassung des Urheberrechts an die Bedürfnisse der Informationsgesellschaft, in GRUR, 1997, p. 859 ff., p. 863 .

88 See Burkert/Hettich/Thouvenin/Harasgama (fn. 87), p. 6o, p. 57.

89 Art. 10 para. 1 CopA.

90 Art. 10 para. 2 CopA.

91 From a perspective of labor law, it is feared that if such an obligation exists, researchers would become unattractive to publishers, even though such an obligation is considered possible under contract law; see Hilty/Seemann (fn. 9), p. 66; see in this context also the polarizing Heidelberger Appell.

92 See Brigitte Bieler, Die Übertragung des Urheberrechts, in Konstellationen des Arbeits-, Auftrags-, Werkvertrags- und Produzentenverhältnisses sowie in ausgewählten Bereichen des Umstrukturierungsrechts, Basler Studien zur Rechtswissenschaft, Privatrecht, Vol. 117, Basel, 2014. For a German perspective, see Joachim Dorschel, Open Access und Urheberrecht: Open Source in neuem Gewand?, in Hagenhoff, p. 235 ff., p. 240 ff. On the topic of transferring the copyright in employment relationships, with a focus on the 
a university repository requires an explicit grant of rights. 93 This stems in part from the creator principle («Schöpferprinzip») of Art. 6 CopA,94 and of Art. 9 para. 2 CopA, 95 whereby the author can decide what, where and when to publish. If deciding to negotiate directly with the publisher, within the scope of the author's contractual autonomy, the authors typically find themselves in a weaker negotiating position. ${ }^{96}$ As a result, the author often - sometimes unwittingly transfers the corresponding «online rights» .97 Nevertheless, simple licenses 98 could facilitate the author's retention of rights without any problem.99 Templates

scientific community, see Manfred Rehbinder, Schweizerisches Urheberrecht, 3rd ed., Bern, 2000, no. $175 \mathrm{ff}$.

93 The University can thus only acquire derivative rights; see Hilty/Seemann (fn. 9), p. 25; Hilty, Urheberrecht, Bern, 2011, no. 314, 316.

94 See, for example, Denis Barrelet/Willi Egloff, Le nouveau droit d'auteur, Commentaire de la loi fédérale sur le droit d'auteur et les droits voisins, 3rd ed., Bern, 2008, p. 34 f.; Hilty/Seemann (fn. 9), p. 24.

95 Barrelet/Egloff (fn. 94), p. 49 f.: Droit de divulgation according to Art. 9 para 2 CopA.

96 For a plea for strengthening the weaker party through mandatory contract law provisions, such as in rental or employment law, see Hilty (fn. 93), Urheberrecht, no. 38. However, it should be noted that the largest Swiss publishers accommodate authors by offering relatively short retention periods: for example, three months at Schulthess, six months at Dike, and, pursuant to Art. 382 para 3 OR, three months at Stämpfli and Helbing. See Bernhard Dengg, Slide 24.

97 See Hilty/Seemann (fn. 9), p. 34 ff., who use the term in reference to the right to upload (reproduction rights within the meaning of Art. 10 para 2 lit. a CopA), and the access right (Art. 10 para 2 lit. c CopA).

98 In contrast to the absolute transfer of rights; see Hilty/Seemann (fn. 9), p. 31 ff. For the permissible extent of the transfer of copyright, see Bieler (fn. 92), p. 45 ff., in particular p. 65 ff.

99 Margo Bargheer, Open Access und Universitätsverlage: Auswege aus der Publication Crisis? in Hagenhoff (fn. 92), p. 173 ff., p. 181. When dealing with repositories, the author should renounce his or her copyright compensation claim; see Dorschel (fn. 92), p. 246 ff. for such licenses can be found online, for example on the SPARC website. ${ }^{100}$ They can then be incorporated into a corresponding contract. ${ }^{101}$

20 The default rules of the law shall apply, if parties did not derogate from these rules by agreement.102 Where Swiss law applies, Art. 381 para. 1 of the Federal Act on the Amendment of the Swiss Civil Code (Part Five: The Code of Obligations, $\mathrm{OR})^{103}$ is of particular relevance. According to this article, only those rights shall be transferred that are actually needed for the implementation of the contract. ${ }^{104}$ If the author concludes a publishing contract with an OA publisher or repository, the reproduction ${ }^{105}$ or access rights ${ }^{106}$ are no longer in the foreground, their place being taken by the technical and salesrelated services of the provider. ${ }^{107}$ The interest of the author in granting a nonexclusive license corresponds with that of the university as operator of the repository. Ideally, the latter has no interest in an

100 The Scholarly Publishing and Academic Resources Coalition.

101 Hilty/Seemann (fn. 9), p. 28.

${ }^{102}$ It should be noted, however, that Art. 380 ff. OR are not mandatory and are therefore outweighed by standard contracts and commercial practices; see Peter Breitschmid, Title 12: Der Verlagsvertrag, in Jolanta Kren Kostkiewicz/Stephan Wolf/Marc Amstutzu/Roland Fankhauser, OR Kommentar Schweizerisches Obligationenrecht, 3rd ed., Zurich, 2016, p. 1080.

103 Of March 30, 1911.

104 The «theory of transfer for purpose» («Zweckübertragungstheorie»); see Reto M. Hilty/Reto Arpagaus, Bundesgesetz gegen den unlauteren Wettbewerb (UWG), Basler Kommentar, Basel, 2013, Art. 381 OR, no. 4; Rehbinder (fn. 92), no. 165. From a German perspective, see Dorschel (fn. 92), p.238 f.

105 Within the meaning of Art. 10 para 2 lit. a CopA.

106 Art. 10 para 2 lit. c CopA.

107 Dorschel (fn. 92), p. 235 ff., p. 238. Related to the publishing contract in the light of technical developments and $\mathrm{OA}$ in publishing contract law, see Hochreutener (fn. 31), p. 12 ff., and p. 154 ff. 
extensive or even commercial exploitation of the rights. ${ }^{108}$ For this reason, problems arise especially when the author is bound by a publishing contract.109 In such cases, negotiations between the university and the publisher seems to be the most promising for all involved. ${ }^{110}$ As in the United States, ${ }^{111}$ cooperating publishers can then benefit from their appearance on the university website. ${ }^{112}$

Altogether, it can be stated that the existing Swiss CopA enables, but does not promote, OA publications. What changes in favor of OA would be possible on the part of the legislature or universities? One approach would be the combination of public and copyright law rules. ${ }^{113}$ Through mandatory rules, the right to make publicly accessible would remain with the copyright holder. Immediately, or after a specified period, the author would have the option or obligation to deposit the work in the repository. ${ }^{114} \mathrm{~A}$ further proposal to introduce

108 Dorschel (fn. 92), p. 235 ff.

109 The publishing contract as the only legally regulated copyright exploitation contract; see Breitschmid (fn. 102), p. 1080 ff. Comprehensively and extensively to the publishing contract; see Hochreutener (fn. 31).

110 Hilty/Seemann (fn. 9), p. $67 \mathrm{ff}$.

${ }^{111}$ For example, at Harvard University; see chap. III.1.

112 In Switzerland, for example, at the University of Basel.

113 One should note the discussion before the insertion of $\S 38$ (4) UrhG in Germany; see Gerd Hansen, Zugang zu wissenschaftlicher Information - alternative urheberrechtliche Ansätze, GRUR Int, 2005, p. 378 ff., 386 ff.; see also Dorschel (fn. 92), p. 242. For Switzerland, see the response of the University of Zurich's Center for Information Technology, Society and Law (ITSL), written by Florent Thouvenin and Daniel Hürlimann. It proposes a change in publishing contract law in favor of authors.

114 Comparable to the German model. However, the resulting problems must by no means be ignored. See chap. III.3. compulsory licenses appears as a relic of an old-fashioned copyright system and is thus only partially effective. ${ }^{115}$ Barrier schemes («Schrankenregelungen») ${ }^{116}$ that benefit the operator of the repository must respect the requirements of the three-step test ${ }^{117}$ - and seem difficult to enforce politically, because they would deprive the author of a part of his or her copyright from the outset. ${ }^{118}$ It should be noted that most of these proposals do not include OA obligations, but try to promote the aims by other means. Suggestions for OA obligations generally relate only to higher education law, as well as to regulations of funding organizations, such as the Swiss National Science Foundation (SNF).

\section{c) Competition Law}

22 Some publishers of reputable scholarly journals hold a quasi-monopolistic position. This is reinforced by several trends. Aspects of competition law are also noted in online platforms with a solid customer base. While offering customers added value, they complicate the entrance into the market for future competitors. ${ }^{119}$ On an individual basis, this situation can be avoided in part by selfarchiving. Collectively and sustainably,

115 Roland von Büren/Lucas David, Schweizerisches Immaterialgüter- und Wettbewerbsrecht, 3rd ed., Basel, 2014, p. 179; Dorschel (fn. 92), p. 242; Reto M. Hilty, Renaissance der Zwangslizenzen im Urheberrecht? in GRUR, 2009, p. 633 ff.; Hilty/Seemann (fn. 9), p. 96.

116 Meaning scholarly publications made accessible without the consent of the copyright holder.

117 Art. 9 para. 2 RBÜ; Art. 13 TRIPS; Art. 10 WCT.

118 Dorschel (fn. 92), p. 245 ff.; Hilty (fn. 93), p. 179, 189; Hilty/Seemann (fn. 9), p. 92 ff.

119 Hartmann, Legal Agenda (fn. 7), p. 35. 
this can happen through the creation and preservation of OA business models. ${ }^{120}$

the promotion of Open Access, there is regular mention of antitrust price control over the large publishing companies, and thus of measures for guaranteeing competition. ${ }^{121}$ If, in the national OA agenda, an obligation to publishing Open Access in institutional repositories is pursued, these repositories become competitors, because they effectively constitute a part of the publishing industry. ${ }^{122}$

\section{The Example of the University of St.Gallen and the National Science Foundation}

24 Self-regulation is clearly on the agenda in the field of research. It determines the forms for publication, communication and reception. ${ }^{123}$ As a result, many institutions in Switzerland already have OA servers or archives. ${ }^{124}$ The various OA strategies at the universities have to be considered separately from the technical implementation. They differ in terms of form, content and institutional embed-

120 For the entire topic, see Max Planck Digital Library Open Access Policy White Paper: Disrupting the Subscription Journals' Business Model for the Necessary Large-Scale Transformation to Open Access.

${ }^{121}$ Hamann (fn. 5), p. 99. Noted alternatives to this are the copyright barrier (based on the English model) and the secondary publication right (based on the German model).

122 Hilty/Seemann (fn. 9), p. 20. The Federal Act on Cartels and other Restraints of Competition (Cartel Act, CartA) and the Federal Act on Unfair Business Practices (UWG) are of particular relevance here. On competition in the publishing industry in general, see Lessig (fn. 33), p. $8 \mathrm{f}$.

123 Hartmann, Legal Agenda (fn. 7), p. 28.

124 A list of various institutional (e.g. university) Swiss archives can be found at OpenDOAR (18 entries) and in the Registry of Open Access Repositories ROAR (19 entries). ding. ${ }^{125}$ The University of St. Gallen, for example, has an OA regulation that governs various aspects. The duties of the researchers include providing bibliographic data, full texts as a pre- or postprint version, and ensuring nonexclusive distribution rights in publishing contracts. A higher level of liability arises with the Implementation Provisions for Doctoral Studies of May 2, 2017. Pursuant to Art. 31 para. 1, the doctoral candidates must declare that they transfer to the university the rights to save the dissertation electronically, to make the dissertation publicly available in data networks and to provide further copies to the professors of the University of St. Gallen.

25 In Switzerland, the Swiss National Science Foundation (SNF) attracted particular attention with its obligation requirements. The aforementioned Vision 2024 aims at introducing and coordinating OA policies, negotiations with publishers (known as offset agreements, or the «offsetting road»), the use of alternative forms of publication, ${ }^{126}$ the coordination and pooling of resources, ${ }^{127}$ the formation of a supportive regulatory framework, the establishment of a national monitoring system, and raising of awareness in general. Different scenarios are feasible. ${ }^{128}$ As co-signatory of the Berlin Declaration, the SNF sees itself as a promoter of OA efforts and is trying to develop a corresponding political frame-

$125 \overline{\text { As an example and as a comparison, see ETHZ, as }}$ policy; UNILU, as guideline; UZH, as guidance.

126 Which would lead directly to the gold road.

127 In particular, the green road approach could be optimized and made more efficient by working with existing (in-house) infrastructures.

${ }^{128}$ See especially the offsetting road, green road and gold road. See chap. III.2. 
work. It is therefore not surprising to contribution recipients that Open Access publication is required. ${ }^{129}$

\section{Challenges for the Establishment of OA Obligations}

26 Different interests of the parties involved - the institutions, individual researchers and representatives of the publishing industry 130 - as well as the international context of $\mathrm{OA}^{131}$ make a possible introduction of OA obligations into a complex project. This circumstance becomes particularly evident when a functioning and reliable OA obligation rule must be transferred to another institution. ${ }^{132}$ For Switzerland, with a decentralized education and research system, ${ }^{133}$ this is not much different. ${ }^{134}$ The legal rules and institutional basis of OA obligations would be of

129 For the detailed requirements of the SNF with regard to open access, see also the Implementing Regulations to the Funding Regulations, especially p. $32 \mathrm{ff}$.

130 Concerning the interests of the researchers, see Judgment of the Federal Supreme Court of Switzerland 1C_40/2017, July 5, 2017, E. 6.2.1 f. These interests must also be articulated. In particular, adequate representation is a challenge. Regarding the representation of authors by the universities and individual faculties, see $\mathrm{Du}-$ ranceau/Kriegsman (fn. 18), p. 92.

${ }^{131}$ See Klara Keutel, Der goldene Weg zur freien Wissenschaft, FAZ, May 7, 2016.

${ }_{132}$ Duranceau/Kriegsman (fn. 18), p. 77. See chap. III.1, 2: The adaptation of the Harvard style to other institutions was successful, especially as the faculties acted as driving forces.

133 See chap. IV.

134 Swiss National Strategy on Open Access, 3. Guiding Principles, 1. Powerful and unified approach, p. 2 f. Not to be forgotten are the politicians and political interests, which are influential in the question of obligation and in the development of a concrete statute. For the role of politics as part of the community in network policy in general, see Dirk Heckmann, Herausforderungen für das Gemeinwesen 2.o, Freiheit und Fairness als Leitmotiv einer neuen Netzpolitik, wie sie in Deutschland diskutiert wird, in digma, 2011, p. $12 \mathrm{ff}$. importance for the implementation, but they are no guarantee of success. Instead, individual researchers need to be convinced of the idea. ${ }^{135}$ Such conviction may arise, in particular, if a similar boost of reputation can be achieved through OA publications. Furthermore, personal advocacy is needed on the part of universities. ${ }^{136}$ While a wide access scheme is in demand for foreign research results, the university's own publications are largely still being held under wraps. ${ }^{137}$

\section{Conclusion}

27 When addressing Open Access, the specific implementation must be distinguished from the vision. ${ }^{138}$ In answering the question of whether an OA obligation can be introduced for researchers in Switzerland, a more concrete framework would be desirable. What must be clarified, in particular, is whether the Swiss legislator in the ongoing revision of the Copyright Act is willing to introduce a secondary publication right («Zweitveröffentlichungsrecht») for researchers. ${ }^{139}$ Furthermore, in relation to Art. $20 \mathrm{BV}$,

$135 \overline{\text { See Priest (fn. 8), p. 377; Duranceau/Kriegsman }}$ (fn. 18), p. 77 ff.; Judgement 1C_4O/2017, July 5, 2017, E. 6.2.1 f. For the generally OA-friendly concept of science, see chap. III.1.a).

${ }_{136}$ Müßig (fn. 52), p. 227. However, it is also stated that currently existing differences in reputation (in the humanities even more pronounced than in the natural sciences) could be overcome relatively quickly by the intensified establishment of OA.

137 Steinhauer (fn. 5), p. 18 ff., 55 f.; see SNF, Open Access to Publications.

${ }^{138}$ See chap. I, II, III. At the same time, universities are seen as the main actors in this implementation process; see Swissuniversities, Aktionsplan, p. $3 \mathrm{f}$.

139 See Swiss Federal Institute of Intellectual Property (IGE), Modernisation of Copyright Law, 7; quoted from Swissuniversities, Aktionsplan, p. 16; see also Michael Baumann, Das neue Urheberrecht bremst Open Access, horizonte, March 8, 2018. 
concretization is needed with regard to the question of whether an OA obligation would be consistent with fundamental rights. 140 At the moment, only sparse case law exists.

A strategies and rules, as bases of an $\mathrm{OA}$ obligation, not only concern the legal sphere, but also social and political issues. Especially when it comes to promoting innovation, a discourse between representatives of the scientific, social, economic and technological spheres would be fruitful. ${ }^{141}$ While supporters see the OA obligation as an effective way to achieve the $\mathrm{OA}$ vision and view it as a future direction for research, ${ }^{142}$ opponents see it as a threat to the existing legal understanding of the publishing industry, and to the culture of books. ${ }^{143}$

29 Keeping this is mind, the question arises as to how to legislate a possible OA obligation: as compulsory or as a «mandatory option» with the possibility of opting out? ${ }^{144}$ Three proposals are being considered as plausible - which ideally would be combined altogether They are: An OA obligation in higher education law with an opt-out option, based on the English

140 See chap. IV.1.a.

141 See chap. IV.3. See, as an example, the Project Inno-Futures at the Universities of Bern and Neuchâtel.

142 As an example, see Swiss National Strategy on Open Access, 6. Implementation, p. 6. For the effective dissemination of knowledge, according to the wishes of researchers, see Shieber (fn. 45), p. $5 \mathrm{ff}$; Fischman Afori (fn. 15), p. $398 \mathrm{ff}$.

143 Especially in Germany, this discussion was already amplified. See chap. III.3. See, for example, the Heidelberger Appell and the numerous countervotes (fn. 91).

144 Steinhauer (fn. 5), p. 44. These can follow funding guidelines (concerning projects that benefit from national research funding) or come directly from university law («Hochschulrecht»); see Hamann (fn. 5), p. 99. model, ${ }^{145}$ the introduction of a secondary publication law, similar to the one in the Federal Republic of Germany, ${ }^{146}$ and an antitrust ${ }^{147}$ price control in view of quasimonopolistic publishing groups. ${ }^{148}$

\footnotetext{
145 See chap. III.2.

146 See chap. III.2.

147 Although, from an antitrust point of view, the existence of a monopoly would be difficult to justify.

148 Hamann (fn. 5), p. 99, with reference to Matthias Seemann.
} 